\title{
Performance in the Construction Industry- A Conceptual and Theoretical Analysis
}

\author{
George Hove, Adewale Banjo \\ UNISA School of Business Leadership, Midrand, South Africa \\ Email: George.hove@telkomsa.net, afreb@yahoo.com
}

Received 3 March 2015; accepted 13 April 2015; published 14 April 2015

Copyright (c) 2015 by authors and Scientific Research Publishing Inc.

This work is licensed under the Creative Commons Attribution International License (CC BY). http://creativecommons.org/licenses/by/4.0/

c. (i) Open Access

\begin{abstract}
Small businesses growth and profitability is a national problem in South Africa (SA) and the Emerging Contractors (ECs) in the construction industry are no exception. ECs are alleged to fail to live up to the expectations of different stakeholders. This paper looks back at the level of understanding of the performance construct especially the ECs and their stakeholders in South Africa. It establishes that there are no unique characteristics that have been translated into the performance construct and contributed by defining performance for ECs in the construction in the context of today's South African changing environment.
\end{abstract}

\section{Keywords}

Performance, Construction Industry, Emerging Contractor, South Africa

\section{Introduction}

The role of Emerging Contractors (ECs) in the economic development of a nation is a controversy [1]. In the Republic of South Africa (RSA), ECs are perceived to be important as instruments of job creation, income generation, economic growth and encouragement of entrepreneurship, because of their ability to work at lower prices and in more remote locations, because of their ability to provide a platform for previously non-participating groups in the sector to enter and secure work, and arising from their local base which helps increase spending in the local economy [2]. Through the Construction Industry Development Board (CIDB), the interest of South Africa government is to see a stronger presence of ECs, in order to reverse historical economic imbalances in income distribution and employment, but the absence of such a presence is a concern for the board, the government agency charged with ensuring construction industry development [3].

There are interventions however, the government put forward to create an enabling environment and to improve the performance of new entrants into the construction industry after 1994 [4]. Amongst the development 
programs that have been initiated by the South Africa government are emerging contractor development models (ECDMs) and emerging contractor development programs (ECDPs) [5] as shown in Table 1.

Internationally, numerous performance frameworks have been developed in research that act as the basis for company's performance measurement system including among others the Balanced Scorecard [6], The European Foundation for Quality Manage (EFQM) Excellence Model in Europe, the Malcolm Baldrige National Quality Award (MBNQA) in the United States, the Deming Prize in Japan and the South African construction excellence model (SACEM).

Despite the government intervention in South Africa and progress made in developing the frameworks, gaps and shortcomings persist on the performance of ECs in South Africa. They continue exhibiting features that include inadequate capacity and low participation in work opportunities. This paper looks back at the level of understanding of the performance construct especially the ECs and their stakeholders in South Africa. The level of understanding and knowledge about the performance concept, seem to be scattered and limited, despite an extensive research in the construction industry.

\section{Problem Statement}

The relative ECs' weak performance has been widely reported in literature [7] which could be attributed, to lack of common understanding of the performance concept among ECs and stakeholders. The term "performance" and how this could be communicated to the wider market, i.e. how it could be understood and interpreted by policy makers, community, potential investors, employees and customers has not been clearly understood. There is however, wide divergent perspective on what constitutes performance within ECs business environment and this has continued to challenge ECs management, construction commentators and practitioners for many years. This paper attempts to establish the common unique characteristics of "performance" and to define performance for ECs in the construction in the context of today's South African changing environment.

\section{ECs Performance: The Conceptual Framework}

Traditionally, performance of contractors is focused on the satisfaction of the clients, the client's agents and consultants in terms of delivery time, budgets and quality. Clients in construction want their projects delivered on time, on budget, free from defects, efficiently, right the first time, safely and by profitable companies. Regular clients expect continuous improvement from their construction team to achieve year on year reductions in project cost and reductions in project time [8]. However, a review of construction literature indicates many areas apart from clients' satisfaction that create confusion in the level of understanding performance construct. As a result, performance in construction is understood from different perspectives by different stakeholders. Recently in South Africa, there are many different types of campaigns and programs that are being called "performance". This is due to changes to the development of social, economic and technological programs. Based on new visions emerging from ECs operational environment, client satisfaction cannot remain the only feature associated with performance in the construction industry considering the existence of the following issues:

- Complaints from different stakeholders relating to: workmanship which is felt to be inferior in some way, the conduct of the ECs in relation to contractual matters and the financial aspects, delays and the time taken

Table 1. Combined models.

\begin{tabular}{c} 
Model \\
$\begin{array}{c}\text { EPWP } \\
\text { ECDPs } \\
\text { EDPs } \\
\text { Enterprise Development Programs for, typically, contractors in Grades } 3 \text { to } 6 \text { who exhibit potential to develop. } \\
\text { IECDM } \\
\text { Realised in the improvement of business management skills, tendering skills, business growth, } \\
\text { CIDB grading and increased employment chances } \\
\text { Programs focusing on improving the performance of established contractors in, typically, Grades } 4 \text { to } 7, \\
\text { such as the Contractor Incubator Programmed in line with the SA Construction Excellence Model }\end{array}$ \\
\hline
\end{tabular}

Source: Research (2014). 
for work to be completed, poor or insufficient communication between the contractor and the client/agent, insufficient supervision of unskilled and semi-skilled staff by principals/responsible persons of the building enterprise and poor housekeeping and disregard for client's adjacent and movable property;

- Promotion of black economic empowerment, the participation of women and the disabled in the economy and the need to transform the construction industry in South Africa;

- Improvement of rural accessibility, increase local contracting capacity and create rural empowerment which ECs are expected to play important role;

- ECs location, rural and urban settings have an effect on the understanding of performance construct. Depending on the location, ECs in rural settings may perceive performance in a different way compared to those in urban settings;

- Application of modern technology and the use of old equipment by ECs;

- ECs' compliance with national, provincial and municipal regulations that include: compliance with construction regulations and standards and environment. ECs' poor response to environment (energy conservation, air quality and environmental sustainability) has been attributed to their poor environmental consciousness.

\section{Performance Construct}

The concept of performance is hard to define, describe and measure systematically [9]. Numerous authors have identified difficulties with performance construct in various countries, although critiques of the UK models are the most prevalent. There are diverse definitions of the performance construct that indicate the term is multi-faceted and subjective in nature. This is so because most public programs have more than one goal and the goal statements tend to be vague, changeable, controversial and at times conflicting. Traditionally, performance has been used to describe concepts such as efficiency, effectiveness, improvement, growth and success and these terms have been used interchangeably by the researchers [10] [11]. [12] suggest that the treatment of performance in research settings is perhaps one of the thorniest issues confronting the academic researcher. This is because what performance means or what are appropriate operational definitions is not always clear. This is supported by [13] who note that definitions of successful performance... and the variables used to measure performance vary widely. For example, [14] identified the main performance criteria of construction projects as financial stability, progress of work, standard of quality, health and safety, resources, relationship with clients, relationship with consultants, management capabilities, claim and contractual disputes, relationship with subcontractors, reputation and amount of subcontracting. Performance thus may have a different set of meanings for small (as opposed to large) firms and consequently it may be inappropriate to apply similar measures to the assessment of performance [15]. Against this background, it is interesting to establish the common understanding by stakeholders of what performance constitutes for ECs in the construction industry in Gauteng province, South Africa.

The concept of firm performance needs to be distinguished from the broader construct of organizational effectiveness [16]. The distinguishing part is given by [12] who offered an enlightening figure of three overlapping concentric circles with the largest representing organizational effectiveness (Figure 1). This broadest domain of organizational effectiveness includes the medium circle representing business performance, which includes the inner circle representing financial performance. Organizational effectiveness covers other aspects related to the functioning of the organization as absence of internal strain and faults, engagement in legitimate activities, resource acquisition and accomplishment of stated goals [17]. Based on [12], business performance is a sub set of organizational effectiveness that covers financial and non-financial outcomes.

In construction business, the ECs performance in relation to owner and stakeholder satisfaction are key and important. It is imperative therefore to show that one has acknowledged the ECs performance taking into account the owners' and stakeholders' satisfaction levels especially when performance measurement is involved. The understanding that performance tries to seek information on efficiency, growth, profit, size, liquidity, success/failure, market share and leverage [18] [19] would be undermined as stakeholders such as communities and governments are interested in different forms of performance other than the ones mentioned by [18].

Traditionally, performance is approached in relation prime assessment of construction projects in terms of success or failure and in relation to the creation of the product as a process [20]. ECs are praised for performance if the project attains the technical performance specifications and/or mission to be performed, and if there is a high level of satisfaction concerning the project outcome among key people in the parent organisation, key 


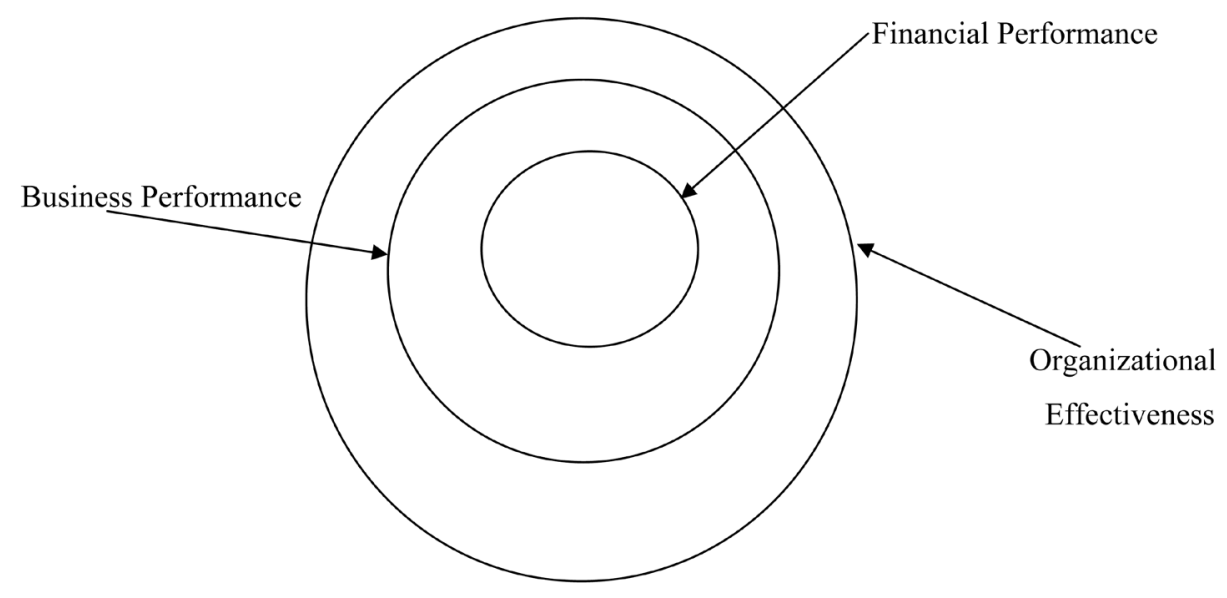

Figure 1. Organizational performance. Source: Venkatraman and Ramanujan (1986).

people in the project team and key users or clientele of the project effort. However, a broader conceptualization of business performance includes indicators of operational performance (non-financial). Under this framework, in the construction sector performance measures have included innovation, quality, time, cost and budget within the domain of business performance [21]. This shows that ECs need to track the satisfaction of various constituencies who have a critical interest in and impact on their firm's performance such as clients in construction sector, employee satisfaction, suppliers, banks, distributors, retailers, stockholders, social performance and environmental performance [21] [22]. Construction ECs must understand stakeholder's needs, avoid defects and improve the perceived quality and value added by their offerings [23].

The term performance has been used in literature to include constructs measuring aspects of performance such as success, survival and growth [11] [24]. These terms are very closely linked and can be used as synonyms. Success is a difficult concept to define because it is multi-faceted [25]. Success is therefore, a subjective concept [11] and can be examined from a broader perspective where the non-financial aspects are taken into account. The emphasis is on the EC owners' and stakeholders' subjective perceptions of success performance. [26] identified the success of small businesses as actual performance equal to or exceeding the business executives' expectations. Thus, success could be financial growth with adequate profits. On the other hand, growth is defined and measured using absolute or relative changes in sales, market share, assets, employment, productivity, profits and profit margins. Based on this definition, ECs growth would be limited because other stakeholders' interests are not incorporated into the definition.

Although the three traditional measures in construction (cost, time and quality) provide an indication as to the performance of a contracting firm, they do not in isolation, provide a balanced view of the firm's performance and usually, are implemented at the end of the project. What makes it difficult to assess whether ECs in South Africa are performing or failing is the lack of nationally accepted definition of "performance" for ECs since the concept has remained vague among stakeholders. However, there is a general understanding for those involved in the construction businesses who perceive performance as the achievement of some predetermined goals while the general public may have different views of performance, which are commonly based on user satisfaction. For example, Clients have own interpretation of performance based on the level of satisfaction required from the projects (cost, time and quality). Employees require satisfaction in human resources practices including job descriptions, wages and salaries, working hours, investment in training, career plans and good bonus policies [27]. Governments and communities have own interpretation of performance based on their interests that include employment creation, income generation, contribution towards national GDP. They also want to know that ECs comply with legal and environmental factors: compliance with health and safety regulations, compliance with environmental policies. Social and environmental performance is considered a way to satisfy communities [28] and governments [29]. The local community expects the venture to make a positive contribution to the quality of local life [25] while ECs owners require satisfaction from own investment in form of return on investment and family employment.

When one examines literature, there is no performance definition if any for ECs with unique characteristics that have been taken into account in the construction industry. This paper contributes by attempting to identify 
the core themes of pillars that should underlie performance definition for ECs in the construction industry. This lack of unique characteristics on performance construct for ECs leaves the sector with limited knowledge about what performance for ECs entail. What seems apparent to stakeholders is general understanding of the performance construct which creates misunderstanding when ECs performance is evaluated.

\section{Motivation and Methodology}

In analysing performance construct among emerging contractors in South Africa, one finds various opinions upon which the construct is understood. This becomes a problem facing the sector and how ECs could be assisted if there is no common understanding becomes a challenge. This article highlights that any attempt to influence ECs' performance should engage all stakeholders and gauges a thorough understanding of their understanding of the performance construct. Otherwise, the issue of ECs' performance would destine to perpetuate unless research is undertaken that examines the business assistance realities of EC executives and stakeholders to better understand those experiences from the perspective of their understanding and abilities.

The population of this research was drawn from the ECs and stakeholders of the construction industry in Gauteng province. Although Gauteng province is the smallest of the nine provinces, it has the highest concentration of construction works in South Africa. Judgemental sampling technique was adopted in choosing key informants, predominantly representatives of ECs, government departments, community, consultants and clients, employees, financial institutions and suppliers. The key informants were contacted as they visited various construction sites to conduct routine construction assessments. The researcher used the opportunity of working on construction sites to conduct in-depth interviews with the executives who provided their perspectives on the performance construct. An interview guide was the instrument used to collect primary data for the study.

\section{Analyses of Results}

Based on the in-depth interviews conducted with key informants, the key attributes on performance construct that emerged are summarised in Table 2. The table helped to identify the common attributes that are perceived by EC executives and stakeholders as they relate to performance construct. The results are presented in columns where each column represents the common performance attributes as they are perceived by representatives from each category of stakeholders. The results demonstrate that EC owners have own perspectives about performance attributes while stakeholders have different perspectives. EC owners focus mainly on financial and nonfinancial attributes that include profit, revenue, return on investment, return on sales and return on equity while stakeholders such as clients focus on attributes that relate to expected quality, delivery time and costs of the project. The results suggest no unique characteristics that exist regarding performance construct as it is understood by ECs and stakeholders.

\section{Conclusion and Recommendations}

From the preceding analysis, the first unique feature to define "performance" is the ability by ECs to consider performance focusing on stakeholder interest which would translate both traditional and non-traditional measures into the definition. Stakeholder interest should be considered as the outcome ECs strive to achieve. [30] note that in construction, performance is evaluated by stakeholders' value judgments and is, thus, framed by their values, experience, and expectations rather than traditional performance factor targets alone.

In order for stakeholders' satisfaction to be achieved, ECs should coordinate resources and activities appropriately in line with the resource based theory.

The EC owners should be motivated by intrinsic and extrinsic factors in order to satisfy stakeholders through appropriate coordination of resources and activities. Intrinsic factors arise from the performance of doing business itself (these include whether the business is profitable and challenging) while extrinsic factors fall outside doing business, and usually include government incentives, enabling environment that accrue to the EC owners.

Enabling culture would allow permeation and sharing of information between ECs and stakeholders that would result in the satisfaction of both parties.

From the preceding discussion this paper contributes by proposing the following "performance" definition for ECs in the construction industry in South Africa. "Performance is a phenomenon consisting of a set of attributes focusing on ECs' stakeholders satisfaction provided in a culture that motivates the EC owners to coordinate resources and activities". By defining ECs performance this way, the unique features that come out 
Table 2. Summarised results on performance attributes.

\begin{tabular}{|c|c|c|c|c|c|c|}
\hline EC owners & $\begin{array}{l}\text { Government } \\
\text { departments }\end{array}$ & Community & $\begin{array}{l}\text { Client and } \\
\text { consultants }\end{array}$ & Employees & $\begin{array}{l}\text { Financial } \\
\text { institutions }\end{array}$ & Suppliers \\
\hline Job creation & Job creation & Job creation & $\begin{array}{l}\text { Poor planning \& } \\
\text { control }\end{array}$ & Job creation & & \\
\hline $\begin{array}{c}\text { BEE } \\
\text { compliance }\end{array}$ & $\begin{array}{c}\text { BEE } \\
\text { compliance }\end{array}$ & BEE compliance & BEE compliance & BEE compliance & & \\
\hline $\begin{array}{l}\text { Safety, health, } \\
\text { environment }\end{array}$ & $\begin{array}{l}\text { Safety, health, } \\
\text { environment }\end{array}$ & $\begin{array}{l}\text { Safety, health, } \\
\text { environment }\end{array}$ & $\begin{array}{l}\text { Safety, health, } \\
\text { environment }\end{array}$ & $\begin{array}{l}\text { Safety, health, } \\
\text { environment }\end{array}$ & & \\
\hline $\begin{array}{l}\text { Development } \\
\text { and training }\end{array}$ & $\begin{array}{l}\text { Development } \\
\text { and training }\end{array}$ & $\begin{array}{l}\text { Contribution } \\
\text { to social } \\
\text { development }\end{array}$ & $\begin{array}{c}\text { Timely completion } \\
\text { of project }\end{array}$ & $\begin{array}{l}\text { Development } \\
\text { and training }\end{array}$ & & \\
\hline Profit generation & $\begin{array}{c}\text { Income } \\
\text { generation }\end{array}$ & $\begin{array}{l}\text { Quality } \\
\text { structures }\end{array}$ & $\begin{array}{l}\text { Quality } \\
\text { structures }\end{array}$ & $\begin{array}{l}\text { Working } \\
\text { conditions }\end{array}$ & & \\
\hline $\begin{array}{l}\text { Cost control } \\
\text { system }\end{array}$ & $\begin{array}{l}\text { Payment } \\
\text { of taxes }\end{array}$ & $\begin{array}{c}\text { Ethical } \\
\text { behaviour }\end{array}$ & Cost control & $\begin{array}{l}\text { Employee } \\
\text { motivation }\end{array}$ & & \\
\hline $\begin{array}{l}\text { Grow market } \\
\text { share }\end{array}$ & Air quality & $\begin{array}{c}\text { New } \\
\text { products }\end{array}$ & $\begin{array}{c}\text { Employee } \\
\text { absenteeism }\end{array}$ & Job security & & \\
\hline Sales growth & Noise level & $\begin{array}{c}\text { Ethical } \\
\text { practices }\end{array}$ & $\begin{array}{l}\text { Disputes \& } \\
\text { Conflicts }\end{array}$ & $\begin{array}{l}\text { Good bonus } \\
\text { policies }\end{array}$ & $\begin{array}{l}\text { Saving of } \\
\text { income }\end{array}$ & \\
\hline $\begin{array}{l}\text { Return on } \\
\text { investment }\end{array}$ & $\begin{array}{l}\text { Contribution } \\
\text { towards GDP }\end{array}$ & $\begin{array}{c}\text { Raise standard } \\
\text { of living }\end{array}$ & $\begin{array}{l}\text { Conformance to } \\
\text { specification }\end{array}$ & $\begin{array}{l}\text { Market related } \\
\text { remuneration }\end{array}$ & $\begin{array}{l}\text { Borrowing } \\
\text { of funds }\end{array}$ & $\begin{array}{l}\text { Decrease } \\
\text { in orders }\end{array}$ \\
\hline $\begin{array}{l}\text { Improved liquidity } \\
\text { of the company }\end{array}$ & $\begin{array}{c}\text { Reduced } \\
\text { reportable } \\
\text { accidents }\end{array}$ & $\begin{array}{c}\text { Raise society’s } \\
\text { needs }\end{array}$ & $\begin{array}{l}\text { Sequencing of work } \\
\text { according schedule }\end{array}$ & $\begin{array}{c}\text { Investment in } \\
\text { human resources }\end{array}$ & $\begin{array}{l}\text { Payment } \\
\text { of interest }\end{array}$ & $\begin{array}{l}\text { Prompt } \\
\text { payment }\end{array}$ \\
\hline Return on assets & $\begin{array}{l}\text { Production of } \\
\text { goods and } \\
\text { services }\end{array}$ & $\begin{array}{l}\text { Education } \\
\text { and sporting }\end{array}$ & $\begin{array}{l}\text { Projects with } \\
\text { memories } \\
\text { of harmony }\end{array}$ & $\begin{array}{c}\text { Clear Job } \\
\text { descriptions }\end{array}$ & $\begin{array}{l}\text { Pension } \\
\text { funds }\end{array}$ & $\begin{array}{c}\text { Market share } \\
\text { growth }\end{array}$ \\
\hline Revenue growth & $\begin{array}{c}\text { Innovation and } \\
\text { learning }\end{array}$ & $\begin{array}{c}\text { Avoid } \\
\text { profiteering }\end{array}$ & $\begin{array}{c}\text { Poor } \\
\text { workmanship }\end{array}$ & $\begin{array}{l}\text { Wages and } \\
\text { rewards policies }\end{array}$ & & \\
\hline $\begin{array}{l}\text { Improved } \\
\text { productivity }\end{array}$ & $\begin{array}{c}\text { Wastes } \\
\text { around sites }\end{array}$ & $\begin{array}{l}\text { Monopolistic } \\
\text { exploitation }\end{array}$ & $\begin{array}{l}\text { Ineffective } \\
\text { monitoring and } \\
\text { supervision }\end{array}$ & $\begin{array}{l}\text { Employee } \\
\text { turnover }\end{array}$ & & \\
\hline Self-fulfillment & $\begin{array}{c}\text { Ethical } \\
\text { behaviour }\end{array}$ & & $\begin{array}{c}\text { Poor } \\
\text { communication }\end{array}$ & $\begin{array}{c}\text { Poor } \\
\text { communication }\end{array}$ & & \\
\hline $\begin{array}{c}\text { Family } \\
\text { employment }\end{array}$ & $\begin{array}{l}\text { Compliance to } \\
\text { Labour laws }\end{array}$ & & $\begin{array}{c}\text { Quality of } \\
\text { decision making }\end{array}$ & Career plans & & \\
\hline $\begin{array}{l}\text { Customer } \\
\text { satisfaction }\end{array}$ & $\begin{array}{l}\text { Participation in } \\
\text { rural development }\end{array}$ & & $\begin{array}{l}\text { Quality of equipment } \\
\text { and raw material }\end{array}$ & $\begin{array}{c}\text { Avoiding } \\
\text { employment } \\
\text { through agencies }\end{array}$ & & \\
\hline $\begin{array}{l}\text { Gross profit per } \\
\text { employee }\end{array}$ & $\begin{array}{l}\text { Aiding large } \\
\text { businesses }\end{array}$ & & $\begin{array}{c}\text { Speed and reliability } \\
\text { of service }\end{array}$ & $\begin{array}{l}\text { Employee } \\
\text { promotion }\end{array}$ & & \\
\hline Good life style & $\begin{array}{l}\text { Research and } \\
\text { development }\end{array}$ & & $\begin{array}{c}\text { Owners’ } \\
\text { competencies }\end{array}$ & $\begin{array}{l}\text { Employment } \\
\text { equity }\end{array}$ & & \\
\hline \multirow[t]{2}{*}{$\begin{array}{l}\text { Pride in running } \\
\text { a successful } \\
\text { business }\end{array}$} & $\begin{array}{c}\text { Comply to } \\
\text { basic conditions } \\
\text { of employment }\end{array}$ & & $\begin{array}{l}\text { Quality assessment } \\
\text { systems used }\end{array}$ & $\begin{array}{c}\text { Safe } \\
\text { workplace }\end{array}$ & & \\
\hline & $\begin{array}{l}\text { Production of } \\
\text { green products }\end{array}$ & & $\begin{array}{l}\text { Number of rework } \\
\text { incidents }\end{array}$ & $\begin{array}{l}\text { Status and } \\
\text { recognition }\end{array}$ & & \\
\hline \multirow[t]{3}{*}{$\begin{array}{l}\text { Conformance to } \\
\text { specification }\end{array}$} & $\begin{array}{l}\text { Improve } \\
\text { infrastructure }\end{array}$ & & $\begin{array}{c}\text { Use of wrong } \\
\text { construction drawings }\end{array}$ & $\begin{array}{c}\text { Acceptable } \\
\text { leadership style }\end{array}$ & & \\
\hline & Create wealth & & $\begin{array}{c}\text { Lack of } \\
\text { leadership skills }\end{array}$ & $\begin{array}{c}\text { Employee } \\
\text { involvement }\end{array}$ & & \\
\hline & $\begin{array}{l}\text { Participation } \\
\text { of women } \\
\text { and disabled }\end{array}$ & & $\begin{array}{l}\text { Incompetency } \\
\text { of ECs }\end{array}$ & $\begin{array}{l}\text { Working } \\
\text { hours }\end{array}$ & & \\
\hline
\end{tabular}


of the definition are clearly identified and including:

- Attributes relate to all measurable that emerge from different stakeholders interacting with ECs businesses;

- Stakeholders refer to all individuals and organisations that can affect or are affected by ECs businesses (refer Table 2);

- Satisfaction relates to the achievement of stakeholders' expected attributes by ECs.

- An enabling culture refers to acceptable values that would enable ECs to execute business operations in a sustainable manner, while;

- Motivation refers to the factors that would induce the ECs to continue coordinating resources and activities in order to satisfy stakeholders.

In conclusion, performance will always remain a contested construct, however, considering regular changes taking place in the South African construction industry which impact on our understanding of ECs performance and based on the changes, there is need to continue revising and reminding ourselves of "what constitutes performance in the construction industry in relation to ECs?”

The definition proposed in this paper is based on the reviewed literature and key informants interviewed in Gauteng province of South Africa. This limits the understanding of performance construct and a national exercise would bring richer understanding of the construct.

\section{References}

[1] Ofori, G. (1990) The Construction Industry: Aspects of Its Economics and Management. Singapore University Press, Singapore.

[2] Dlungwana, W.S. and Rwelamila, P.D. (2005) Contractor Development Models for Promoting Sustainable BuildingA Case for Developing Management Capabilities of Contractors. Proceedings of the 2005 World Sustainable Building Conference, Tokyo, 27-29 September 2005, 4208-4215.

[3] Windapo, A. and Cattell, K. (2011) Research Report: Mapping the Path to Becoming a Grade 9 Contractor. University of Cape Town, Cape Town.

[4] Hauptfleisch, D., Lazarus, S., Knoetze, T. and Liebenberg, S. (2007) An Integrated Emerging Contractor Development Model for the Construction Industry: Practical Implementation and Statistical Quantification. http://researchspace.Csir.co.za/dspace/bitstream/10204/1850/1/Hauptfleisch_2007

[5] Buys, F. and Ludwaba, D. (2012) The Potential of Built-Environment Professionals' Contribution towards Emerging Contractor Development. ACTA Structilia, 19, 74-89

[6] Kaplan, R.S. and Norton, D.P. (1992) The Balanced Scorecard Measures That Drive Performance. Havard Business Review, 70, 71-79. https://hbr.org/2005/07/the-balanced-scorecard-measures-that-drive-performance

[7] Greyling, E. (2012) Opportunities for Employment Creation through SME Development in the Construction Sector, Free State. International Labour Organisation, Pretoria.

[8] MAIA Intelligence (2009) KPIs for Construction Industry. http://maia-intelligence.com/kpis-for-construction-industry/

[9] Hancott, D.E. (2005) The Relationship between Transformational Leadership and Organisational Performance in the Largest Public Companies in Canada. Doctoral Dissertation. Capella University, Minneapolis.

[10] Akbaba, A. (2012) Business Performance of Small Tourism Enterprises: A Comparison among Three Sub-Sectors of the Industry. An International Journal of Tourism and Hospitality Research, 23, 177-195. http://dx.doi.org/10.1080/13032917.2012.662907

[11] Reijonen, H. and Komppula, R. (2007) Perception of Success and Its Effect on Small Firm Performance. Journal of Small Business and Enterprise Development, 14, 689-701. http://dx.doi.org/10.1108/14626000710832776

[12] Venkatraman, N. and Ramanujam, V. (1986) Measurement of Business Performance in Strategy Research: A Comparison of Approaches. Academy of Management Review, 11, 801-814.

[13] Murphy, G.B., Trailer, J.W. and Hill, R.C. (1996) Measuring Performance in Entrepreneurship Research. Journal of Business Research, 36, 15-23. http://dx.doi.org/10.1016/0148-2963(95)00159-X

[14] Thomas, S.N., Palaneeswaran, E. and Kumaraswamy, M.M. (2002) A Dynamic E-Reporting System for Contractors' Performance Appraisal. Advances in Engineering Software, 33, 339-349. http://dx.doi.org/10.1016/S0965-9978(02)00042-X

[15] Keats, B.W. and Bracker, J.S. (1988) Toward a Theory of Small Firm Performance: A Conceptual Model. American Journal of Small Business, 12, 41-58.

[16] Santos, J.B. and Brito, L.A. (2012) Towards a Subjective Measurement Model for Firm Performance. Brazilian Administration Review, 9, 95-117. http://dx.doi.org/10.1590/S1807-76922012000500007 
[17] Cameron, K. (1986) A Study of Organizational Effectiveness and Its Predictors. Management Science, 32, 87-112. http://dx.doi.org/10.1287/mnsc.32.1.87

[18] Cho, H. and Pucik, V. (2005) Relationship between Innovativeness, Quality, Growth, Profitability and Market Value. Strategic Management Journal, 26, 555-575. http://dx.doi.org/10.1002/smj.461

[19] Glick, W.H., Washburn, N.T. and Miller, C.C. (2005) The Myth of Firm Performance. Proceedings of the Annual Meeting of American Academy of Management, Honolulu, 5-10 August 2005.

[20] Kagioglou, M., Cooper, R. and Aouad, G. (2001) Performance Management in Construction: A Conceptual Framework. Construction Management and Economics, 19, 85-95. http://dx.doi.org/10.1080/01446190010003425

[21] Faridi, A. and El-Sayegh, S. (2006) Significant Factors Causing Delay in the UAE Construction Industry. Construction Management and Economics, 24, 1167-1176. http://dx.doi.org/10.1080/01446190600827033

[22] Kotler, P. and Keller, K.L. (2006) Marketing Management. 12th Edition, Pearson Prentice Hall, Upper Saddle River.

[23] Marx, H.J. (2012) Construction Industry Indicators Affecting Contractors. Journal for the Advancement of Performance Information and Value, 4, 119-132.

[24] Brush, C.G. and Vanderwerf, P. (1992) A Comparison of Methods and Sources of Obtaining Estimates of New Venture Performance. Journal of Business Venturing, 7, 157-170. http://dx.doi.org/10.1016/0883-9026(92)90010-O

[25] Wickham, P.A. (2001) Strategic Entrepreneurship: A Decision-Making Approach to New Venture Creation and Management. 2nd Edition, Financial Times/Prentice Hall, London.

[26] Luk, S.T.K. (1996) Success in Hong Kong: Factors Self-Reported by Successful Small Business Owners. Journal of Small Business Management, 34, 68-74.

[27] Harter, J.K., Schmidt, F.L. and Hayes, T. (2002) Business Unit Level Relationship between Employee Satisfaction: A Meta-Analysis. Journal of Applied Psychology, 87, 268-279. http://dx.doi.org/10.1037/0021-9010.87.2.268

[28] Chakravarthy, B.S. (1986) Measuring Strategic Performance. Strategic Management Journal, 7, 437-458. http://dx.doi.org/10.1002/smj.4250070505

[29] Waddock, S.A. and Graves, S.B. (1997) The Corporate Performance-Financial Performance Link. Strategic Management Journal, 18, 303-319. http://dx.doi.org/10.1002/(SICI)1097-0266(199704)18:4<303::AID-SMJ869>3.3.CO;2-7

[30] Liu, A.M.M. and Walker, A. (1998) Evaluation of Project Outcomes. Construction Management and Economics, 16, 209-219. http://dx.doi.org/10.1080/014461998372493 